\title{
Sulfur- and seleno-containing amino acids
}

\author{
Maria Wróbel - Martha H. Stipanuk • \\ Noriuki Nagahara
}

Published online: 6 May 2011

(C) The Author(s) 2011. This article is published with open access at Springerlink.com

This special issue is devoted to professor Toshihiko Ubuka (1934-2008), a distinguished Japanese biochemist who, in his scientific life, researched the metabolism and function of cysteine, sulfur nutrition, modification and renaturation of proteins and the possible significance of cysteine metabolites in antioxidation processes in liver cell mitochondria. Recollections about professor Ubuka, written by M. Wróbel and professor Ubuka's wife and son (Wróbel et al. 2011), open this volume.

Sulfur is one of the prevalent elements in the human body and is present, most often, in the sulfur-containing amino acids: methionine, cysteine, homocysteine (and related disulfides, cystine and homocystine), and taurine. Selenium, in the form of selenocysteine, occurs in 25 proteins in the human proteome (Kryukov et al. 2003).

This volume contains a selection of contributions originally presented at the 11th International Congress on Amino Acids and Proteins held in Vienna, August 3-7, 2009. However, additional manuscripts dedicated to the sulfur- and seleno-containing compounds submitted subsequent to the Congress have also been included. Topics presented in reviews illustrate the present challenges in this

M. Wróbel $(\bowtie)$

Jagiellonian University Medical College, Kopernika 7 St, 31-034 Kraków, Poland

e-mail: mbwrobel@cyf-kr.edu.pl

M. H. Stipanuk

Division of Nutritional Sciences, Cornell University, Ithaca, NY 14853, USA

N. Nagahara

Department of Environmental Medicine,

Nippon Medical School, Tokyo, Japan area of research and should stimulate further investigations. The reviews begin with a very important opening review about pyridoxal $5^{\prime}$-phosphate-dependent enzymes currently known to catalyze cysteine and selenocysteine conjugates $\beta$-lyase reactions, presented by Cooper et al. (2011), one of the fathers of this field, and by Pinto et al. (2011). Four reviews, presented by J. Papenbrock, N. Nagahara, R. Hondal, and K.A. Ahmed, concern the role of sulfur and selenium in enzymatic proteins: sulfur transferases (Papenbrock et al. 2011; Nagahara 2011) and thioredoxin reductase (Hondal and Ruggles 2011) and redox-sensitive proteins (Ahmed et al. 2011). Thiol dioxygenases, proteins in the cupin superfamily, were described by Stipanuk et al. (2011), the expert in the field of cysteine dioxygenase. The benefits of sulfur compounds used in health products (popular items include the active ingredients of garlic) or hydrogen sulfide in cellular signaling are presented by Melino et al. (2011) and Kimura (2011), respectively.

The second part of this issue is a group of original articles that investigated the sulfur signaling agent $\mathrm{HS}^{-}$ or $\mathrm{S}^{\circ}$ ), its generation and its possible role in the regulation of cell proliferation (Jurkowska et al. 2011a, b; Cartini et al. 2011); how cells respond to cysteine deprivation (Sikalidis et al. 2011); the role of cysteine residues in the redox-regulated porphobilinogen synthase activation (Sawada et al. 2011); and the formation and determination of some derivatives of sulfur-containing amino acids (Choudhary et al. 2011; Xu and Xu 2011; Glowacki et al. 2011).

We hope that the articles published in this special issue will continue to generate an interest in such unique biological agents as sulfane sulfur and hydrogen sulfide, shed light on a new aspect of regulation of protein function via the sulfur amino acids, and will further our understanding of the sulfur amino acids. 
Acknowledgments The guest editors express their gratitude to Dr. Gert Lubec, Editor-in-Chief, for the opportunity to prepare this special issue of amino acids.

Open Access This article is distributed under the terms of the Creative Commons Attribution Noncommercial License which permits any noncommercial use, distribution, and reproduction in any medium, provided the original author(s) and source are credited.

\section{References}

Ahmed KA, Sawa T, Akaike T (2011) Protein cysteine $S$-guanylation and electrophilic signal transduction by endogenous nitronucleotides. Amino Acids (in this issue). doi:10.1007/s00726010-0535-1

Cartini F, Remelli W, Dos Santos PC, Papenbrock J, Pagani S, Forlani F (2011) Mobilization of sulfane sulfur from cysteine desulfurases to the Azotobacter vinelandii sulfurtransferase RhdA. Amino Acids (in this issue). doi:10.1007/s00726-010-0529-z

Choudhary A, Pua KH, Raines RT (2011) Quantum mechanical origin of the conformational preferences of 4-thiaproline and its $S$-oxides. Amino Acids (in this issue). doi:10.1007/s00726010-0504-8

Cooper AJL, Krasnikov BF, Niatsetskaya ZV, Pinto JT, Callery PS, Villar MT, Artigues A, Bruschi SA (2011) Cysteine $S$-conjugate $\beta$-lyases: important roles in the metabolism of naturally occurring sulfur and selenium-containing compounds, xenobiotics and anticancer agents. Amino Acids (in this issue). doi:10.1007/ s00726-010-0552-0

Głowacki R, Bald E, Jakubowski H (2011) An on-column derivatization method for the determination of homocysteine-thiolactone and protein $N$-linked homocysteine. Amino Acids (in this issue). doi:10.1007/s00726-010-0521-7

Hondal RJ, Ruggles EL (2011) Differing views of the role of selenium in thioredoxin reductase. Amino Acids (in this issue). doi:10.1007/s00726-010-0494-6

Jurkowska H, Uchacz T, Roberts J, Wróbel M (2011a) Potential therapeutic advantage of ribose-cysteine in the inhibition of astrocytoma cell proliferation. Amino Acids (in this issue). doi: 10.1007/s00726-010-0593-4
Jurkowska H, Placha W, Nagahara N, Wróbel M (2011b) The expression and activity of cystathionine- $\gamma$-lyase and 3-mercaptopyruvate sulfurtransferase in human neoplastic cell lines. Amino Acids (in this issue). doi:10.1007/s00726-010-0606-3

Kimura H (2011) Hydrogen sulfide: its production, release and functions. Amino Acids (in this issue). doi:10.1007/s00726010-0510-x

Kryukov GV, Castellano S, Novoselov SV, Lobanov AV, Zehtab O, Guigo R, Gladyshev VN (2003) Characterization of mammalian selenoproteomes. Science 300:1439-1443

Melino S, Sabelli R, Paci M (2011) Allyl sulfur compounds and cellular detoxification system: effects and perspectives in cancer therapy. Amino Acids (in this issue). doi:10.1007/s00726010-0522-6

Nagahara N (2011) Intermolecular disulfide bond to modulate protein function as a redox-sensing switch. Amino Acids (in this issue). doi:10.1007/s00726-010-0508-4

Papenbrock J, Guretzki S, Henne M (2011) Latest news about the sulfurtransferase protein family of higher plants. Amino Acids (in this issue). doi:10.1007/s00726-010-0478-6

Pinto JT, Lee JI, Sinha R, Macewan ME, Cooper AJL (2011) Chemopreventive mechanisms of $\alpha$-keto acid metabolites of naturally occurring organoselenium compounds. Amino Acids (in this issue). doi:10.1007/s00726-010-0578-3

Sawada N, Nagahara N, Arisaka F, Mitsuoka K, Minami M (2011) Redox and metal-regulated oligomeric state for human porphobilinogen synthase activation. Amino Acids (in this issue). doi: 10.1007/s00726-010-0570-y

Sikalidis AK, Lee JI, Stipanuk MH (2011) Gene expression and integrated stress response in $\mathrm{HepG} 2 / \mathrm{C} 3 \mathrm{~A}$ cells cultured in amino acid deficient medium. Amino Acids (in this issue). doi:10.1007/ s00726-010-0571-x

Stipanuk MH, Simmons CR, Andrew Karplus P, Dominy JE Jr (2011) Thiol dioxygenases: unique families of cupin proteins. Amino Acids (in this issue). doi:10.1007/s00726-010-0518-2

Wróbel M, Ubuka T, Ubuka S (2011) Remembering professor Toshihiko Ubuka (1934-2008). Amino acids (in this issue). doi: 10.1007/s00726-010-0476-8

$\mathrm{Xu} C, \mathrm{Xu} \mathrm{J}$ (2011) Versatile synthesis of $\alpha$-substituted taurines from nitroolefins. Amino Acids (in this issue). doi:10.1007/s00726010-0655-7 